\title{
W. P. S. J. の紹介
}

\section{W.P.S.J., 29, No. 2，1973 日次紹介}

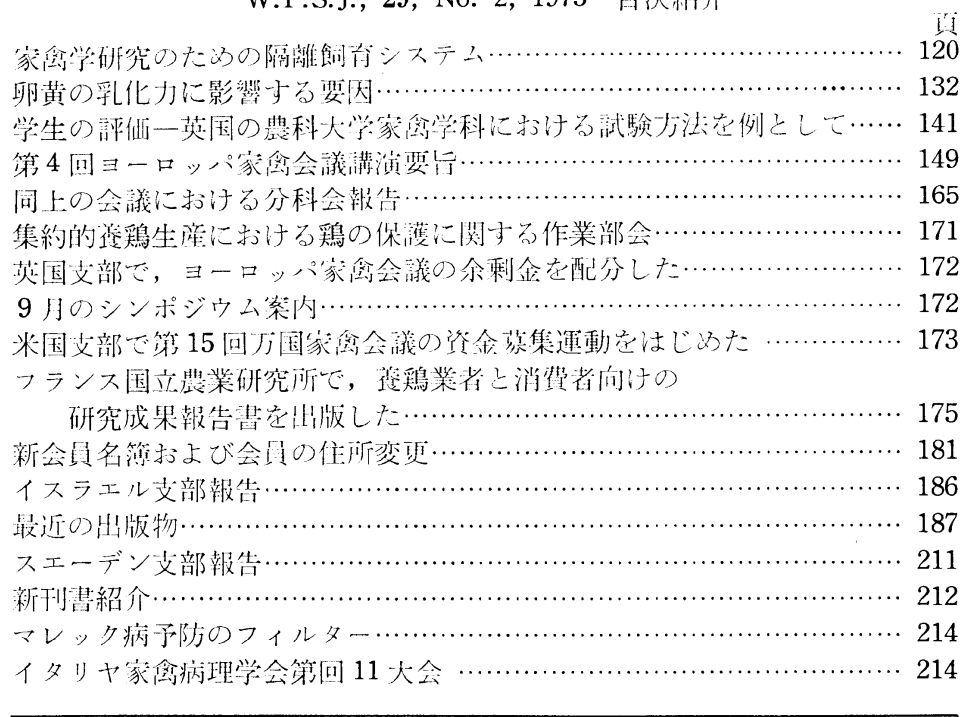

\section{家离学研究のための隔離飼育システム}

J.R. Timms and D.M. Cooper: World's Poultry Sci. J., 29, 120 (1973)

微生物や病原菌のいない動物索飼青与るこ上者目的上 与る施設としては，多種類のものが開発されている。そ 机には，サルモネラ菌の研究の場命の上うに监に部庋在 什切っただけという簡単なもの和ら，呼吸器病菌やウイ ルスを防除与るための完全な沪聥，殺菌装罚を一汁たも

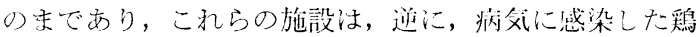
在飼育与る目的で使用さ机るこ上もある。

用語の定義を明確にするた放に，国際実験動物委員会 (International Committee on Laboratory Animals) で法つぎの上うにきめている。無菌動物と注，䦥鎖した 施設で飼育して，一切の微生物や寄生虫が検出されなく 烄った動物在いう。SPF 動物上は，特定の微生物や寄 生虫は検出さ扎ないが，そ机以外のもの法，いてもよい ものである。

無菌ヒナのた的の隔離施設は 1895 年から検䞑さ机て いるが，1948 年にノートルダム大学ではじめて成功し た．英国でも無菌ヒナ㧍よび無菌日本ウズラの研究が進 み, SPF ヒナの生産にも役立っている。

無菌七ナ用隔離施設には，属質のもの上軟質のものが 西る。硬質のものは，ステンレス・スチール製のもの心゙ 多く，オートクレーブや薬品で殺菌吉るようになってい る。完全に気密にする型のものもあるが，多く法微陽压

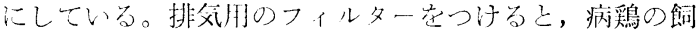
育用施設としても使朋できる。

軟質の天幕型隔雄施設は，プラスチック製のもので， 安俩であって多用さ机ているが，火占注破机やすいこ上 である。殺菌剂として，過酶酸（2\%）にアルキル・アミ ルスルホン酸塩 (alkylamylsulphonate) 花 $0.1 \%$ 混じ

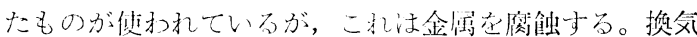
装罥のフィルター在通与ことにより，压力が $10 \sim 20 \mathrm{~cm}$ 低下寸るのが普通で，流速は $3 \sim 5 \mathrm{~m}^{3} /$ 琮のものが多い。 SPF ヒナの隔離施设に汇種々のデザインがあるが， 一般に, SPF ヒナは陽压で，病鶏の場合は陰压で飼育 与る。筆者らは, 幅 $91 \mathrm{~cm}$, 卧さ $274 \mathrm{~cm}$, 高さ $74 \mathrm{~cm}$

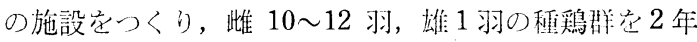
間飼育している。これ注，合板の底にプシスチック板を 張り，ガラス践維板で補強したものである。この施設 で，ロードアイランドレッドレライトサセックスの 2 鶏 種のSPF 鷄在飼っているが，普通に成熟して，产卵率 にも滛はない。SPF 䳕のほうが卵質はすぐれているよ うである。また，死亡率注低下し，死因注主に，力ニバ リズム，脱症（prolapse）叔よび緊炎であった。

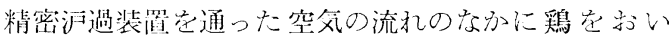
て，ほこりや微生物注父流により吹飛ばすことにより， SPF 鷄学飼青与る設俏も考光られている。これは，一 方方向に空父夌流与もので, 流速は $0.4 \mathrm{~m} /$ 秒程度であ る。この考え方による育雛施設も淓えられている。 
汇過した空父を送りこえで，鷄舎内学陽圧に保つこと により，隔離の目的在達しようという試みもいくつかな されている。クーパー (COOPER) は, この型の鴗舎で, マレック病の侵入は防げなかったが, 呼吸器病ウイルス 法る期間検出されなかったし，その他の病原菌につい てはこの施設で SPF 鵴を飼育することに成功している。 この型の陽圧隔離鷄舎では，作業員を通じて病原菌が侵 入すること危険がある。作業にあたり，作業衣をとりか 壳，作業帽をから゙るのが普通である。特定の人が 1 つの 鵴舎を受持つように与るが，その人が休えだり，病気の ときに管理上困ることがおきる。

病鴗隔離施設は, 1940 年に最初に作ら机ており, 獣 医学上の研究に活用されている。これも大きさやタイプ が種々であるが，強力な換気扇で窒内の空父を，沪過し た上で吸出して，陰圧にするようになっている。

無菌動物用施設と SPF 動物用施設の殺菌, 消毒装置 は本質的に同じで，ステンレス製の場合はオートクレー ブで, プラスチックの場合は, 過酢酸, 酸化エチレン, などの薬品や $\gamma$-線照射が利用される。

無菌鶏の場合, 飼料の殺菌が大切であるが, 栄養価を 損なわないため， $\gamma$-線照射が用いられている。多数の $\mathrm{S}$ $\mathrm{PF}$ 鵎を飼夺する場合， $\gamma$-線照射流高価となるので, ペ レット化などの処置ですますととがある。現在，臭化メ チルで消毒玄ることを検討している。

隔離が完全であるかどうか，定期的に検査する必要が 亦る。無菌動物の場合, 微生物の侵入は, 臭いで父付く ことができるが, SPF 鷄の場合は, 血清学的, 細菌学 的, あるい槣生虫学的な, 種々の検査をしなければな らない。微生物が侵入したときには，それが装筫の欠陷 によるものか，人為的な経路によるものかをよく調べる ことも大切である。

（吉田 実）

\section{卵黄の乳化力に影響する要因}

F.E. Cunningham and P. Varadarajula: World's Poultry Sci. J., 29, 131 (1973)

卵黄は，水分 $50 \%$, 脂質 $33 \%$, 蛋白質 $16 \%$, 透析可 能物 $2 \%$ 以下といった組成で, 典型的な乳化物であると ともに，乳化剂としての働きも寸る。卵黄の機能的な特 性に影響する要因は多いが，まだよく解明されていない 面が多い。

殺菌処理の温度の影響については, $60 \sim 63^{\circ} \mathrm{C} て ゙ 4$ 分 間という条件では, 卵黄, 卵白の安定性, マヨネーズの 嗜好性には影響がないとさ机ている。乳化力について は, $61^{\circ} \mathrm{C}$ では差がないが, $63 \sim 65^{\circ} \mathrm{C}, 4$ 分間では乳 化力が高まると報告されている。

均質化（ホモジネーション）処理により卵黄の乳化力
は低下する，影響はない，あるい流まるといったまち まちな結果が報告されており，今後種々の条件において その影響を検討する必要があるう。

卵黄を $0^{\circ} \mathrm{C}$ で 4 力月販蔵しても乳化力は低下しない という報告がある。卵黄を脱水西るいは乾燥したりする と変質して, 泡立ち, 水溶性などが失なわれるが, 乳化 力については乾燥方法で異なり, 真空乾燥では低下寸る が，噴霧乾燥で注高まるという報告もある。しかし， 、 ヨネーズの油分の分漓倠の程度は, 噴霧乾燥卵黄を使う場 合, 凍結乾燥卵黄老使う場合上り多く, 凍結卵安使う場 合が最も少ないという報告もある。

卵黄の乳化力に影劉を打よぼす卵黄の成分についても 多くの研究がある。コレステロール，レシチン，レシト ・プロテイン (lecitho-protein), エーテル不溶部与な わち蛋白質とリポ蛋白筫, リビチン (livetins), リボビ テリン (lipovitellin), リポビテレニン (lisovitellenin) などについて検討されている。しかし, 卵黄の成分をと り出したものでは, その乳化力は全卵の乳化力に抢よば ないことから, 卵黄の乳化力は, そのらちの策一の成分 の働きによるもので佉なく，複合的な作用と考元られて いる。

ステアロイルー2ーラリチリン酸ナトリウム（sodium stearoyl-2-lactylate）を $0.05 \%$ 添加すると乳化力が高 まるが，0.02\%の添加では効果はない。レシチンを添 加しても効果がなく，レシチンとコレスチロールの拮抗 作用が考元ら机ている。卵黄に卵白を加党ると, 卵白含 量の増加に応じて卵黄の乳化力が低下し, 卵白 $20 \%$ で 乳化力はほぼ半隇している。この成績から，マヨネーズ を作る場合, 卵白の混入割合を $20 \%$ 以下，できれ证 $15 \%$ 程度に与るとよいといえる。

飼料中の油脂の種類によっては, 卵黄乳化力に差を生 じない。鷄種によって，卵黄の組成に差があることが知 られているが, 卵黄の乳化力については, 筆者らにより, 褐色レグホーン種と白㑔レグホーン種とで差があり, 前 者の卵黄の乳化力が後者の乳化力の䄪 2 倍であることが 報告された。

$\mathrm{pH}$ も関係していて，中性のとき乳化力が最も強く， 酸性にすると低下寸る。

鷄の年齢も関係していて，50 週龄までは，卵黄の乳 化力に大差がないが，それより老龄になると乳化力が高 まり, 75 週龄の乳化力では, 有意差が認められた。

(吉田 実)

\section{集約的養鶏生産における鵎の保護に関する作業部会} World's Poultry Sci. J., 29, 171 (1973)

ストックホルムのスエーデン国立獣医学研究所のリン 
ドグレン (LINDOGREN) 博土は，本学会執行部より“集

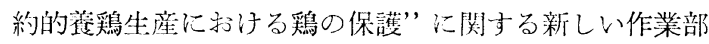
会を組織するように依頼をうけ，この問題に関し，大要 つぎのような文書它各国支部に発送した。

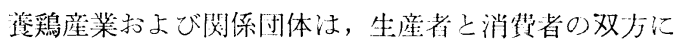
刘し、できるだけ反刘のないように生座をする防衛措犆

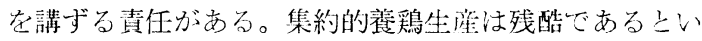
う大首の非難は十分考慮し交け机ばならないし，同時に 産業界では常にこの問题を考虑していることを血知させ ることが重要である。この部会では，つぎのうな項目

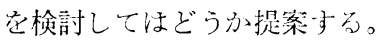

1. 動物虛待防止に関与る法律，集䄪的音産に网与る 行政的規制とその監視態勢

2. 養鵎産業に括ける集約の程度と笑状

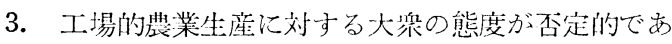
るかどらか，またその程度と対像

4. 集約的生産に打ける䳕の管理, 福祉, 生態に䦥号 万研究計画とその成果

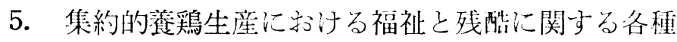
の指整の評価を目的と古る研究計画（各種の環境条作下 に打ける䧗床化学的反度老含）

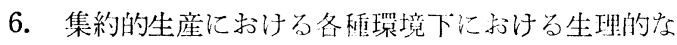
反匛関与万研究部画とその成果

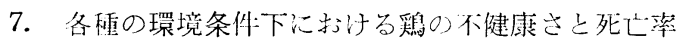
について原因安明示して研究与ること

8. 集約的養鵎生産が残酷であるという大衆の非難に
芯ずるための計画ないし提案

これらの項目は，作業部会構成国の文部で指名された

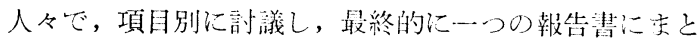
めることを提唱する。

部会の構成は 10〜12 名とし, 〔゙き狄ば 1973 年の初 めに発足し，1973 年6 月に活報告舅ができるようにし たい。

(肯田实)

\section{マレック病予防のフィルター}

マレック病は，伝染性が強く死し率が高いウイルス性 の病気であってこのウイルス㳔非などのほこりに付 着して空父中定はこ泟机，急速に伝染吉る。垁験によれ ば，ウイルス宫含空父に 30 分閒ふれただけで，高い 発病率在示した。

こ秃に刘し，1ミリ・ミクロン程度の微粒子の93〜 97\%竧捕促与るフィルターが洘案され，こ机により空 父突へて感染与るマレック将の䂆防ができるようになっ た。このフィルターはフフィルター它通した空気を送り 込えで，鵎舎内の圧力が外気压より高くするような構造 の毮舎に適用するものである。

このフィルター在使った実験区からはマレック病が発 生しなかったが，ウイルスを含を空気にさらした対照区 では，134 羽中 132 羽が発病した。また， 1 ミリ・ミク ロンのほこりの 45\% 索通すようなフイルター党つけた

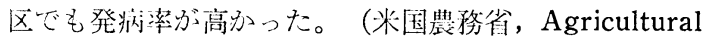
Research 1972 年 4 月号上り报䊉)

（吉田实） 